\title{
Pengaruh Penggunaan Synonym Recognition dan Spelling Correction pada Hasil Aplikasi Penilaian Esai dengan Metode Longest Common Subsequence dan Cosine Similarity
}

\author{
Mohammad Nur Cholis, Erni Yudaningtyas, Muhammad Aswin \\ Program Studi Magister Teknik Informatika Universitas Brawijaya,Malang,Indonesia
}

\begin{tabular}{lrr} 
KEYWORDS & \\
\hline Synonym & Recognition, & Spelling \\
Correction, & Essay & Assessment \\
Application, & Longest & Common \\
Subsequence, Cosine Similarity. & \\
\multicolumn{2}{l}{ CORRESPONDENCE } \\
\hline
\end{tabular}

Phone:

E-mail: cholis8918@gmail.com

\section{PENDAHULUAN}

Dalam berbagai bahasa pasti memiliki kata-kata yang memiliki kesamaan arti meski kata tersebut berbeda, misalnya dalam bahasa indonesia yaitu kata saya. Dalam bahasa indonesia kata saya memiliki banyak sinonim kata seperti aku, abdi, ana, gua. Jika ada sebuah sistem atau aplikasi yang dibuat untuk memahami bahasa manusia maka sistem atau aplikasi tersebut juga harus dapat memahami kasus seperti kata bersinomin ini. Maka dari itulah dikembangkan suatu cara untuk mengenali sinomin yang disebut synonim recognition. Synonim recognition ini bekerja dengan cara mengubah kata bersinonim kekata utamanya.

\section{A B S T R A C T}

Essay assessment application is a must assess the similarity of meaning of the answer typed by the examinee with the answer key used as a benchmark for the correctness of the answer. Where an essay answer is a natural human language data that can have word synonyms and there is a possibility of input errors caused by typing errors (spelling errors). For this reason, it is necessary to have a study that can measure how influential the use of synonym recognition and spelling correction on the results of essay assessment applications. In this study, the data used to carry out testing were exam data on Indonesian subjects, cultural arts and science with the number of questions for each exam were 5 questions, each of which was attended by 24 students. So that from each test there will be 120 answers. The test results show that the use of synonym recognition and spelling correction on the results of essay assessment applications can improve accuracy and reduce the value of root mean square error (RMSE).

aplikasi penilaian esai adalah harus menilai kemiripan makna dari jawaban yan diketik oleh peserta ujian dengan kunci jawaban yang digunakan sebagai patokan kebenaran jawaban. Dimana jawaban esai adalah data bahasa alami manusia yang bisa memiliki sinonim kata dan ada kemungkinan kesalahan input yang disebabkan karena kesalahan pengetikan (kesalahan ejaan). Untuk itu perlu ada sebuah penelitian yang dapat mengukur seberapa berpengaruhnya penggunan synonim recognition dan spelling correction pada hasil aplikasi penilaian esai. Pada penelitian ini data yang digunakan untuk melakukan pengujian adalah data ujian pada mata pelajaran bahasa indonesia, seni budaya dan IPA dengan jumlah soal masing-masing ujian adalah 5 soal yang masing-masing ujian tersebut diikuti oleh 24 pelajar. Sehingga dari setiap ujian akan terdapat sebanyak 120 jawaban. Hasil pengujian menunjukkan bahwa penggunaan synonym recognition dan spelling correction pada hasil aplikasi penilaian esai dapat meningkatkan akurasi dan memperkecil nilai root mean square error (rmse).

Selain masalah sinomin, sistem atau aplikasi yang dibuat untuk memahami bahasa manusia juga harus dapat memahami bahkan harus dapat mengoreksi kata yang diketik oleh penguna. Proses seperti ini disebut spelling Correction. Kesalahan dalam mengetik sangat lumrah terjadi dilakukan oleh seseorang. Hal tersebut bisa disebabkan ketidaktahuan atau terburu-buru dalam mengetik. Kesalahan pengetikan biasanya terjadi karena karena kesalahan huruf, penyisipan huruf, hilangnya huruf, dan tertukarnya letak huruf. Aloritma yang dapat digunakan pada proses spelling Correction adalah algoritma levenshtein distance[1][2].

Salah satu contoh sistem atau aplikasi dibangun untuk memahami bahasa manusia adalah aplikasi penilaian esai. Dimana pada aplikasi tersebut sistem atau aplikasi harus menilai 
kemiripan makna dari jawaban yan diketik oleh peserta ujian dengan kunci jawaban yang digunakan sebagai patokan kebenaran jawaban. Sebuah jawaban bisa saja memiliki sebuah kata yang bersinomin atau ada kata yan salah dalam pengetikan dimana hal seperti ini seharus sistem atau aplikasi dapat mengatasi dan memahami.

Untuk itu penelitian ini akan mencari tahu seberapa besar pengaruh penggunaan synonim recognition dan spelling correction pada aplikasi penilaian esai.

\section{TINJAUAN PUSTAKA}

\section{Ujian Esai}

Ujian esai merupakan ujian dimana pertanyaan yang diajukan menuntut pelajar untuk menjawab dengan cara menguraikan, menjelaskan, mendiskusikan, membandingkan, memberikan alasan, dan bentuk sejenis menggunakan kata-kata serta bahasa sendiri [3]. Ujian esai digunakan untuk mengatasi kelemahan daya ukur soal objektif dan cocok untuk mengukur hasil belajar yang level kognisinya lebih tinggi dan bersifat kompleks [3]. Ujian bentuk esai ini sangat baik digunakan untuk melatih pelajar mengorganiasikan pikiran-pikirannya, mengeluarkan ide atau pendapatnya dengan menggunakan kata-kata sendiri dan melatih penalaran [4].

\section{Pengoreksian Ejaan (Spelling Correction)}

Spelling Correction adalah proses yang digunakan untuk mengoreksi kesalahan pengejaan. Spelling Correction ini bertujuan memberi saran berupa kata atau kumpulan kata untuk memperbaiki kata yang dianggap salah [1]. Disebut terjadi kesalahan pengejaan jika kata tersebut tidak ditemukan dalam kamus. Kesalahan ejaan sering kali terjadi karena kesalahan huruf, penyisipan huruf, hilangnya huruf, dan tertukarnya letak huruf [2].

\section{Pengenalan Sinonim (Synonym Recognition)}

Synonym recognition adalah teknik yang digunakan untuk mengenali kata dengan penulisan berbeda namun memiliki makna yang sama. Synonym recognition diperlukan karena hampir setiap kata khususnya dalam bahasa indonesia memiliki sinonim. Proses synonym recognition dilakukan dengan cara mengecek kata dalam kamus sinonim, jika kata tersebut ada pada kamus sinonim maka kata tersebut diubah menjadi kata utamanya [5].

\section{METODE PENELITIAN}

\section{Alat dan Bahan}

Alat yang digunakan dalam penelitian ini terdiri dari perangkat keras dan perangkat lunak. Berikut ini adalah rincian alat yang digunakan :

- Perangkat keras (laptop)

- Processor : Intel(R) Core(TM) i5-4200U

- Hardisk : $500 \mathrm{~Gb}$
- RAM : DDR3 4GB

- Perangkat lunak

- Sistem Operasi Windows 10

- XAMPP

- JDK 1.8.0

- Netbeans IDE 8.2

Bahan penelitian adalah data yang digunakan untuk melakukan pengujian. Data tersebut adalah soal ujian esai, jawaban ujian esai pelajar dan kunci jawaban yang berupa pedoman penskoran serta sebagai pembanding dengan penilaian dari sistem adalah data nilai ujian pelajar yang dinilai manual oleh pengajar. Untuk mendukung penelitian ini dibutuhkan juga daftar kata dasar dan daftar kata sinonim.

\section{Tahap Penelitian}

Tahap penelitian yang digunakan dalam sistem penilaian jawaban ujian esai ini terdiri dari beberapa tahap yaitu identifikasi masalah, perancangan sistem, implementasi dan yang terakhir adalah analisis dan penarikan kesimpulan. Proses tersebut dijelaskan pada Gambar 1.

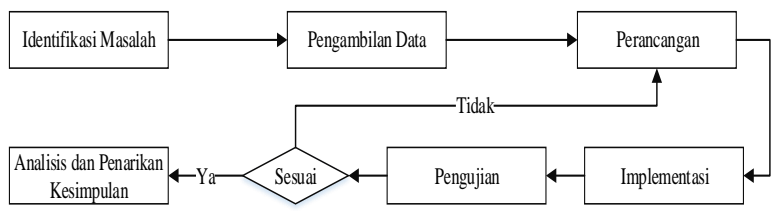

Gambar 1. Tahap Penelitian

\section{- Identifikasi Masalah}

Pada tahap ini dilakukan pengkajian untuk mengidentifikasi masalah yang akan diangkat. Identifikasi masalah dilakukan dengan menentukan hal-hal penting dalam penyelesaian permasalahan dengan cara menganalisis kebutuhan perancangan sistem penilaian jawaban ujian esai. Tahap ini dilakukan dengan mengkaji jurnal-jurnal dan buku-buku terkait.

\section{- Pengambilan Data}

Data yang digunakan untuk penelitian berupa soal ujian esai, jawaban ujian esai pelajar ber-Bahasa Indonesia berupa teks narasi dan kunci jawaban dari soal beserta pedoman penilaian jawaban soal serta sebagai pembanding dengan penilaian dari sistem adalah data nilai ujian pelajar yang dinilai manual oleh pengajar. Data tersebut didapatkan dari ujian pada mata pelajaran bahasa indonesia, seni budaya dan IPA serta Daftar kata dasar dan sinonim.

\section{- Perancangan}

Tahap perancangan digunakan untuk menggambarkan analisis kebutuhan berdasarkan permasalahan dan perkiraan solusi yang akan diterapkan. Perancangan diperlukan supaya proses implementasi sesuai dengan yang diharapkan dan dapat berjalan terarah. Flowchart Gambar 2. mengambarkan tahapan proses yang terjadi pada Aplikasi. 


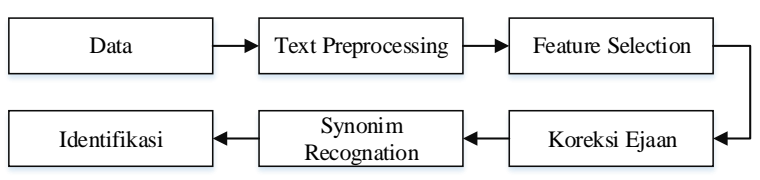

Gambar 2. Flowchart Aplikasi Penilaian Jawaban Esai

Proses pada aplikasi dimulai dengan memasukkan data. Kemudian data tersebut melalui tahap text preprocessing yang terdiri dari proses case folding dan tokenizing. Setelah melaui proses text prepocessing, data kemudian diproses kembali ditahap feature selection. Dimana pada tahap feature selection ini dilakukan filtering dan stemming. Hasil dari tahap feature selection inilah yang menjadi input untuk proses koreksi ejaan (spelling correction). Hasil spelling correction kemudian diproses lagi dengan synonym recognition. Hasil dari rangkaian proses tersebut yang akan dihitung dengan metode longest common subsequence dan cosine similarity untuk mendapatkan nilai sebagai rekomendasi aplikasi.

Spelling correction dilakukan untuk memberikan daftar kata rekomendasi perbaikan ejaan (penulisan) kata yang dianggap salah oleh sistem. Kata yang dianggap salah ejaannya adalah kata yang tidak ada pada kamus kata dasar, kamus sinonim, dan daftar kunci jawaban untuk soal tersebut. Proses pengoreksian ejaan hanya dilakukan pada daftar kata jawaban pelajar. Proses spelling correction dilakukan dengan metode levenshtein distance.

Synonym recognition adalah untuk mengurangi keberagaman kata pada daftar kata dengan cara mengubah kata yang bersinonim dengan kata utama, proses ini diharapkan akan memperkecil keberagaman kata sehingga dapat meningkatkan tingkat akurasi di tahap identification.

\section{- Implementasi}

Pada penelitian ini sistem akan dibangun dengan bahasa pemrograman JAVA. Cara kerja dari sistem adalah seperti yang telah dipaparkan pada subbab perancangan.

\section{- Pengujian}

Pengujian dilakukan untuk mengetahui performa sistem. Pengujain dilakukan dengan menghitung akurasi dan root mean square error (RMSE). Akurasi digunakan untuk menghitung keakuratan nilai yang direkomendasikan oleh sistem. Semakin banyak nilai rekomendasi sistem yang sama dengan nilai sebenarnya (penilaian oleh pengajar) menunjukkan semakin akuratnya hasil dari sistem. Akurasi sistem didapatkan dengan menggunakan persamaan dibawah ini [6] :

$$
\text { Akurasi }=\frac{\text { Jumlah Identifikasi Benar }}{\text { Jumlah Data }} \times 100 \%
$$

RMSE digunakan untuk mengetahui nilai error dari nilai yang direkomendasikan oleh sistem terhadap nilai sebenarnya. Semakin kecil nilai RMSE menunjukkan semakin baik nilai yang direkomendasikan oleh sistem. RMSE dihitung dengan persamaan [7] :

$$
\operatorname{RMSE}=\sqrt{\frac{\sum_{i=1}^{n}(A-F)^{2}}{n}}
$$

Dengan :

$\begin{array}{ll}\mathrm{A} & =\text { Nilai seharusnya }(\text { penilaian oleh pengajar) } \\ \mathrm{F} & =\text { Nilai rekomendasi sistem }\end{array}$

\section{- Penarikan Kesimpulan dan Saran}

Tahap ini adalah tahap terakhir dari pelaksanaan penelitian. Pada tahap ini, hasil pengujian kemudian dianalisa. Dari hasil analisa tersebut kemudian diambil kesimpulan sebagai hasil akhir dari penelitian.

\section{PEMBAHASAN}

\section{Aplikasi Penilaian Esai}

Aplikasi penilaian esai dengan metode longest common subsequence dan cosine similarity yang dirancang dengan tambahan fitur synonim recognition dan spelling correction ini dibuat dengan bahasa pemrograman java. Aplikasi penilaian esai yang telah dibuat memiliki dua halaman yaitu

\section{- Halaman Koreksi}

Halaman Koreksi adalah halaman yang diperuntukan untuk melakukan proses penilaian pada jawaban esai. Pada halaman ini berisi form-form yang harus diisi untuk melakukan penilaian dan dihalaman ini juga hasil penilaian jawaban esai akan ditampilkan.

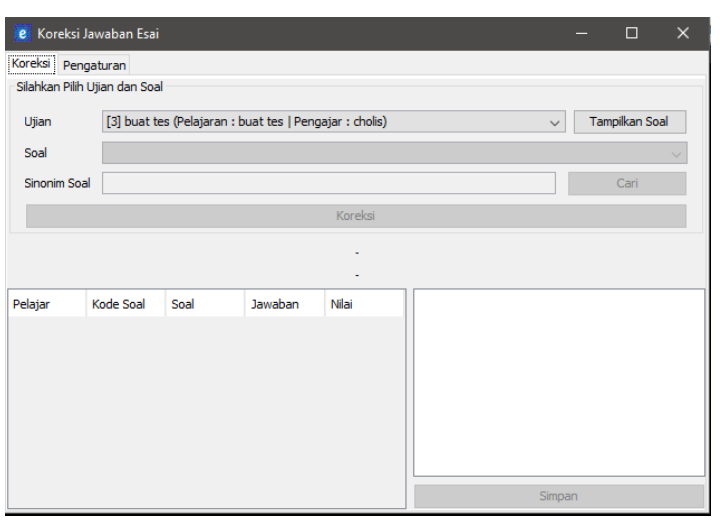

Gambar 3. Aplikasi penilaian esai halaman koreksi

\section{- Halaman Pengaturan}

Halaman Pengaturan adalah halaman yang berisi pengaturan yang dapat diubah-ubah untuk keperluan proses penilaian oleh aplikasi. Pada halaman ini pengguna dapat mengatur apakah penilaian oleh aplikasi akan ditambahkan proses synonim recognition dan spelling correction atau tidak. 


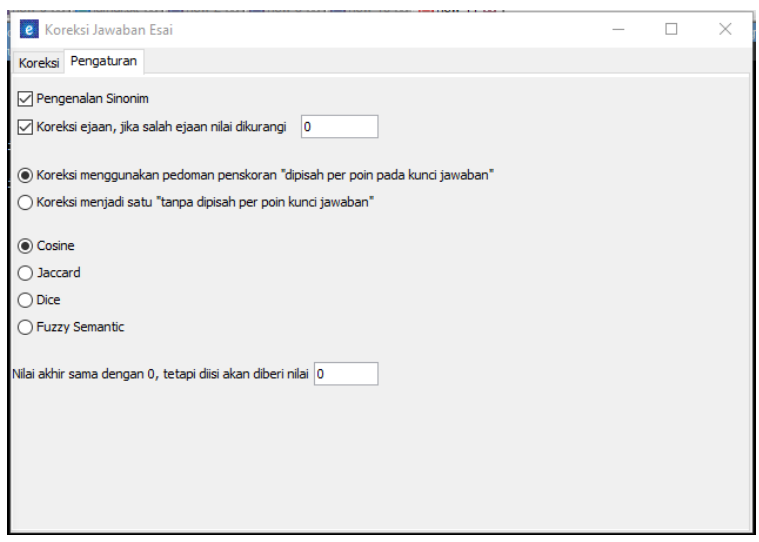

Gambar 4. Aplikasi penilaian esai halaman pengaturan

\section{Data Pengujian Sebagai Input Aplikasi}

Data-data yang dibutukan untuk melakukan penilaian jawaban esai dengan aplikasi yang telah dibuat terdiri dari :

\section{- Data jawaban esai}

Data jawaban esai ini diperoleh dari data yang telah diinput pelajar ketika menjawab soal pada sistem ujian online. Sistem ujian online sendiri dibuat terpisah dengan aplikasi penilaian. Sistem ujian online tersebut yang dibuat berbasis web dengan bahasa pemrograman PHP. Sistem ujian online dapat diakses pada alamat http://uraianessay.net.

Untuk menentukan jawban esai mana yang akan dilakukan penilaian, form-form yang perlu diisi pada aplikasi penilaian esai adalah memilih ujian dan memilih soal.

Data yang digunakan untuk melakukan pengujian pada penelitian ini adalah data ujian pada mata pelajaran bahasa indonesia, seni budaya dan IPA dengan jumlah soal masingmasing ujian adalah 5 soal yang masing-masing ujian tersebut diikuti oleh 24 pelajar. Sehingga dari setiap ujian akan terdapat sebanyak 120 jawaban. Pertanyaan esai dari ujian-ujian tersebut dibatasi hanya untuk pertanyaan "sebutkan".

\section{- Daftar kata bersinonim}

Daftar kata bersinonim dibutuhkan pada proses synonim recognition. Data ini didapatkan dari website KBBI online dan kamusbesar.com. Daftar kata bersinonim ini disimpan dalam file dengan tipe data *.txt. File dengan tipe data *.txt inilah yang diinput pada form sinonim dihalaman koreksi pada aplikasi penilaian esai.

\section{- Daftar kata dasar}

Daftar kata dasar dibutukan pada proses spelling correction. Dimana kata yang terdapat pada daftar kata dasar itulah yang dianggap benar. Sama seperti Daftar kata bersinonim, Daftar kata dasar juga didapatkan dari website KBBI online dan kamusbesar.com serta disimpan dalam file dengan tipe data *.txt. Daftar kata dasar ini akan diload otomatis oleh aplikasi penilaian esai ketika aplikasi dijalankan.

\section{Tahapan dan Hasil Pengujian}

Pengujian dilakukan dalam 2 tahap. Pengujian pertama dilakukan proses penilaian jawaban esai tanpa mengaktifkan fitur synonim recognition dan spelling correction. Pengujian kedua dilakukan proses penilaian jawaban esai dengan mengaktifkan fitur synonim recognition dan spelling correction. Pengujian dilakukan untuk mengetahui performa dari aplikasi yang berupa akurasi dan root mean square error (RMSE). Nilai akurasi dan (RMSE) tersebut didapatkan dari hasil perbandingan nilai yang hasil dari aplikasi dengan nilai pengoreksian manual oleh pengajar.

Pada tahap pertama pengujian didapatkan hasil akurasi dengan persentase rata-rata adalah 58,33 \% dengan nilai RMSE sebesar 4.65. Hasil akurasi dan RMSE untuk masing-masing mata pelajaran dapat dilihat pada tabel 1

TABEL 1

Akurasi dan RMSE aplikasi penilaian tanpa proses synonim recognition dan spelling correction

\begin{tabular}{lcc}
\hline \hline Ujian & Akurasi & RMSE \\
\hline IPA & $51,67 \%$ & 5,97 \\
Seni Budaya & $50.00 \%$ & 4,05 \\
Bahasa Indonesia & $\mathbf{7 3 , 3 3 \%}$ & $\mathbf{3 , 9 3}$ \\
\hline Rata-rata & $58,33 \%$ & 4,65 \\
\hline \hline
\end{tabular}

Pada tahap kedua pengujian didapatkan hasil akurasi dengan persentase rata-rata adalah adalah 93,61\% dengan nilai RMSE sebesar 0,85. Kesalahan penilaian oleh aplikasi dikarenakan adanya kesalahan pengetikan yang berupa adanya spasi pada sebuah kata misalnya "Iri tabilitas" yang seharusnya "Iritabilitas" tanpa spasi dan kata-kata yang tidak dipisahkan oleh spasi misalnya "berkembangbiak" yang seharusnya "berkembang baik". Kesalahan tersebut disebabkan karena proses spelling correction belum dapat menangani kesalahan pengetikan seperti hal diatas. Hasil akurasi dan RMSE untuk masing-masing mata pelajaran dapat dilihat pada tabel 2 .

TABEL 2

Akurasi Akurasi dan RMSE aplikasi penilaian dengan proses synonim recognition dan spelling correction

\begin{tabular}{lcc}
\hline \hline \multicolumn{1}{c}{ Ujian } & Akurasi & RMSE \\
\hline IPA & $92,50 \%$ & 1,02 \\
Seni Budaya & $90,83 \%$ & 0,75 \\
Bahasa Indonesia & $\mathbf{9 7 , 5 0 \%}$ & $\mathbf{0 , 7 9}$ \\
\hline Rata-rata & $93,61 \%$ & 0,85 \\
\hline \hline
\end{tabular}

Dari dua tahap pengujian tersebut menunjukkan bahwa penggunaan synonym recognition dan spelling correction dapat meningkatkan akurasi dengan rata-rata sebesar 35,28\% dan memperkecil RMSE dengan rata-rata sebesar 3,80. 


\section{KESIMPULAN DAN SARAN}

Berdasarkan hasil pengujian yang telah dilakukan menunjukan penambahan synonim recognition dan spelling correction pada aplikasi penilaian esai dengan metode longest common subsequence dan cosine similarity dapat meningkatkan hasil akurasi penilaian. Tingkat akurasi aplikasi dengan penambahan synonim recognition dan spelling correction sebesar 93,61\% dengan nilai root mean square error (RMSE) sebesar 0,85. Hasil akurasi tersebut meningkat $35.28 \%$ dan dapat memperkecil nilai RMSE sebesar 3,80 dari hasil aplikasi penilaian esai dengan metode longest common subsequence dan cosine similarity tanpa penambahan synonim recognition dan spelling correction.

Saran untuk penelitian selanjutnya adalah memperbaiki proses spelling correction untuk mengatasi kesalahan pengetikan pada penggunaan spasi disebuah kata dan proses spelling correction untuk mengenali kata-kata yang harusnya dipisakan oleh spasi.

\section{REFERENSI}

[1] Braddley, M. O., Fachrurrozi, M \& Yusliani, N. 2017. Pengoreksian Ejaan Kata Berbahasa Indonesia Menggunakan Algoritma Levensthein Distance. Prosiding Annual Research Seminar 2017 Computer Science and ICT.

[2] Dwitiyastuti, R. N., Muttaqin, A. \& Aswin M. 2013. Pengoreksi Kesalahan Ejaan Bahasa Indonesia Menggunakan Metode Levenshtein Distance. Jurnal Mahsasiswa Teknik Elektro Universitas Brawijaya, http://elektro.studentjournal.ub.ac.id/ Diakses tanggal 20 November 2017.

[3] Astiti, K. A. 2017. Evaluasi Pembelajaran. Yogyakarta : Penerbit Andi (Anggota IKAPI).

[4] Sary, Y. N. E. 2015. Buku Mata Ajar Evaluasi Pendidikan. Yogyakarta : Penerbit Deepublish (Grup Penerbitan CV BUDI UTAMA).

[5] Jody, Wibowo, A. T., \& Arifianto, A. 2015. Analsis dan Implementasi Algoritma Winnowing dengan Synonym Recognition pada Deteksi Plagiarisme untuk Dokumen Teks Berbahasa Indonesia. Bandung : Teknik Informatika Fakultas Teknik Informatika Telkom University.

[6] Hamzah, A. 2014. Sentiment Analysis Untuk Memanfaatkan Saran Kuesioner dalam Evaluasi Pembelajaran dengan menggunakan Naive Bayes Classifier (NBC). Yogyakarta : Prosiding Seminar Nasional Aplikasi Sains \& Teknologi (SNAST) 2014.

[7] Murray, P. W., Agard, B. \& Barajas, M. A. 2018. Forecast of individual customer's demand from a large and noisy dataset. Computers \& Industrial Engineering 118 (2018) 33-43 . ScienceDirect. 